Heat, as it is usually taught, does not come into the course at all; and, in what is intended for a oneyear course, the compilers have had to be rigorously selective in other directions as well. They have concentrated on what they believe to be fundamental and what can be well taught. They report that the course has proved itself in practice, and the tests given to the pupils are certainly exacting. I was able to obtain a specimen set, and $I$ can only say that I should not care to tackle them after a hard day spent determining coefficients of expansion.

Prof. Francis L. Friedman, of the Massachusetts Institute of Technology, describes the development of the text-book in an appendix, and lists the 200 or so contributors to the programme. They must be proud of their achievement. G. R. Noakes

\section{MATERIALS FOR REACTORS}

Reactor Handbook, Vol. I

Materials. Edited by C. R. Tipton, Jr. Second edition, revised and enlarged. Pp. xv+1207. (New York : Interscience Publishers, Inc. ; London : Interscience Publishers, Ltd., 1960.) 2608.

THE first edition of this handbook was published by the United States Atomic Energy Commis sion before the 1958 Geneva Conference, at a time when little atomic energy information had been released. It is not surprising, therefore, that considerable expansion and revision of the data have been necessary in such a rapidly expanding field and with the declassification of much of the earlier material. In particular, both liquid and gaseous reactor materials have now been included and the number of authors contributing extended to some 130 reactor specialists. The majority of the data has been drawn from U.S. Atomic Energy Commission reports, many of which are still classified, with generally only brief mention of British and other European work. It is claimed that the subject-matter is current to about the spring of 1958 , which would suggest that little of the information released at the 1958 Geneva Conference is included.

It is only possible to indicate briefly the scope of a volume of 1,200 pages which covers a wide range of materials. In a general introductory section, brief surveys are made of radiation damage and of the health and safety aspects involved in handling the special materials in the nuclear energy industry. About $\mathbf{a}$ third of the book is devoted to the production and properties of fuels, which include those based on uranium, plutonium and thorium metals both in solid and liquid form and as ceramics, aqueous solutions and molten salts. A most comprehensive list of canning and control materials is considered and the moderators reviewed are hydrogen-containing compounds, graphite and beryllium-base materials of interest. The properties of both gaseous and liquid metal coolants are detailed together with compatibility data relevant to reactor operation. A section on shielding materials covers their physical and mechanical properties and behaviour under irradiation. The volume concludes with a selected list of references dealing with the constitution of various binary alloys, which is in addition to a large number of equilibrium diagrams of technological interest distributed throughout the text.

Certain aspects of reactor technology of somewhat limited interest are described in considerable detail, whereas other problems, the elucidation of which has occupied a great deal of effort, are not dealt with adequately. For example, swelling of uranium metal fuels which can severely restrict their life under certain operating conditions, is barely mentioned. and the section on radiation damage in beryllium could justifiably be expanded. This also applies to the problems associated with pressure vessel steels, which could be considered in much greater detail. The section on magnesium alloys only briefly mentions the magnox series which were developed by British workers and adopted as the canning material for the first seven Central Electricity Generating Board nuclear power stations and ignores the zirconiumbearing $Z A$ alloy which the French have developed successfully for their reactors. One is left with the impression that the handbook was prepared to satisfy the interests of United States reactor technologists up to 1958 rather than to present a more comprehensive and general survey of reactor materials. Nevertheless, it is a valuable reference book and contains wealth of useful information.

B. W. Mотт

\section{ENZYMES AND CANCER}

\section{Chemistry of Enzymes in Cancer}

By Prof. Franz Bergel. (A Monograph in American Lectures in Living Chemistry.) Pp. xi+122. (Spring field, Ill.: Charles C. Thomas; Oxford: Blackwell Scientic Publications, 1961.) 44s.

HIRTY years ago biochemists were hopefully seeking for qualitative differences in metabolism between normal and tumour cells which might explain their radically different biological behaviour. That search is presumably over, and we are left with only a few quantitative differences, most of them of dubious relevance to the problem of the causation of cancer.

Prof. Bergel starts from the working hypothesis that these differences, which are the outward signs of changes in the deoxyribonucleic acid constitution of the cells, are related to the abnormal properties of cancer cells, and that if the metabolic differences could, by any therapeutic means, be removed, then the cells would revert to normal behaviour.

In Part 1 he outlines the three major kinds of hypothesis which attempt to relate enzymes to cancer: (1) the 'faulty' respiration theory of Warburg; (2) the generalization of Greenberg that all tumours possess a similar enzymic constitution; (3) the 'deletion' theory, due chiefly to Potter, according to which the cancer cell has lost certain protein constituents, probably concerned in the synthesis of enzymes; and he criticizes each in the light of recent biochemical developments. There follows a detailed discussion of the present state of knowledge with respect to certain selected groups of enzyme systems, namely, those concerned with nucleic acid catabolism, which are deficient in tumours; those concerned with protein and amino-acid catabolism, which are deficient at least in some tumours; and the enzymes of carbohydrate breakdown, where, among many other differences, phosphorylase is deficient. All these changes are in the direction of providing an increased potential for cell division.

Part 2 deals with the possibilities of acting on tumour cells in vivo in such a way as to correct the faults in their metabolism and restore them to 